\title{
ON APPLYING LEŚNIEWSKI'S ONTOLOGY TO THE ANALYSIS OF FICTIONAL OBJECTS
}

This paper discusses the validity of Leśniewski's Ontology (in short LO) in the analysis of fictional objects. Such efforts have been taken by K. Ajdukiewicz, W. Marciszewski and J. Pelc. Firstly, the author points out the distinctive features of fictional objects: ontological incompleteness, double structure of predication and the possibility of inconsistency. Subsequently, the main features of the $\mathbf{L O}$ are described. What follows is the examination of LO's adequacy in discussing incomplete and inconsistent objects. The conclusion follows that we can use LO to analyze incomplete objects; nevertheless it is not sufficient for the analysis of inconsistent objects.

Keywords: K. Ajdukiewicz, S. Leśniewski, W. Marciszewski, J. Paśniczek, J. Pelc, logic of fiction, classical logic, incompletness, inconsistency

1 .

Fictional objects are (in the everyday meaning of the word) nonexistent and accompanied by a specific language context - the work of fiction. The same does not mean that we apply a different ontological status to those nonexistent objects which occur in a more general language context, and those not accompanied by one (vide a golden mountain, a married bachelor, etc.). Whereas, the emphasis on the position of the former does have a certain methodological justification. Namely, as they appear in broader language contexts, some of the characteristic traits of nonexistent objects are better visible than when considering such objects in isolation.

At the same time, it is important to draw a distinction between stating that they are nonexistent objects and claiming that they have no ontological status at all. By evoking a well known thesis by Brentana, we can observe that every act has an object, is aimed at an object - the same applies not only to acts aimed at real objects, but also to untethic acts, inadequate acts, or acts of literary creation. We can therefore conclude that nothing about the statement quoted above is fundamentally inconsistent or nonsensical, which in other words simply means that a work of fiction does indeed refer to something at all.

The problem of fictional objects is closely related to the logical problem of empty names. Names such as "Sherlock Holmes", "Hamlet" or "golden mountain" do not have referents in the real world, consequently they cannot function within the classical predicate calculus in the same way as names that do have such referents. It is ruled out by the following proposition:

$$
\exists x(x=a)^{2}
$$

\footnotetext{
${ }^{1}$ Dr Jacek Gurczyński, Instytut Filozofii, Uniwersytet Marii Curie-Skłodowskiej w Lublinie.

${ }^{2}$ Notably, the opinion that classical logic cannot be applied to the construction of ontology of fictional object is not indisputable. There is a possibility, as observed by A. Biłat (personal communication), of enriching the language of classical ontology through the addition of second order predicates (e.g. the predicate - "the object $a$ has an intentionally attributed quality $P "-I[P, a]-$ which could possibly allow the use of that logic in the
} 
The modern discussion on this issue originates from the famous dispute between Russell and Meinong about the designation "golden mountain". Russel gained the upper hand in the dispute when he presented his theory of descriptions, which included a rejection of objective interpretation of fictional names, thus significantly substantiating his reductionist paradigm. Without going too deep into the dispute between the supporters of the reductionist and non-reductionist approach to ontology, although one must express one's inclination towards the latter, let us confine ourselves to quoting a rather characteristic comment by B. Smith:

"Philosophical logicians have assumed, under the pressure of exaggerated Ockhamism, that they must compete with each other to produce theories which have the very least ontological complexity which is required for the solution of given problems or for the explanation of given phenomena. My suggestion is that this process ought more properly to be put into reverse, that philosophical logicians should be aiming rather always to surpass each other in the production of systems ontologically ever more complex, that the philosophical laurels should go not to he who can explain important categories of entities away, but to the philosopher who can provide convincing reasons for an extension of our ontology, or who can provide arguments cogent enough to rescue entities which have come to appear problematic, even though this will often lead to a diminution in the ontological status which those entities are to be conceived as possessing. We should adopt, that is to say, Bochenski's maxim: why make it simple, if it can be complicated? Taken seriously this maxim would, of course, lead to an exaggeration as reprehensible as that of the old perverted Ockhamism. But then the Bochenskian and not the Ockhamist can appeal to the tailor's defence: it is much easier to fashion an acceptable suit of clothes from cloth which has been cut too large than from insufficient cloth, or from cloth which has been cut too quickly, and with greater attention to symmetry and rectilinearity than to the shape of the body it is intended to fit." 3

Fictional objects, objects created in the course of conscious acts of creation, are identified by the qualities attributed to them by the author in the given work of fiction. "The set of such attributes (qualities) is the constitutive moment of the given object of fiction, i.e. it determines the identity of the object." ${ }^{4}$ By adopting a very broad

discussed analyses. The question remains open until such time when the above suggestion is more carefully considered and analysed. However, the fact itself that this sort of reservations exist, necessitates a more thorough justification of the assumption that classical logic is inapplicable in the analysis of fiction.

${ }^{3}$ B. Smith, Smith B., Ingarden vs. Meinong on the Logic of Fiction, "Philosophy and Phenomenological

Research", 16, 1980, p. 47. For a more detailed argument in favour of the opinion that we are obliged to adopt a specific realm of objects of fiction, see e.g. B. Smith, Ingarden vs. Meinong on the Logic of Fiction, "Philosophy and Phenomenological Research", 16, 1980, p. 93-105, J. Paśniczek, Logika fikcji [Logic of Fiction], Wydawnictwo UMCS, Lublin 1984, idem, Meinongowska wersja logiki klasycznej [Meinongian Version of Calssical Logic], Wydawnictwo UMCS, Lublin 1988, idem, Problemy logiki fikcji [Problems of the Logic of Fiction], [w:] Język, znaczenie, rozumienie, relatywizm [Language, Meaning, Comprehension, Relativism], red. Z. Muszyński, Wydawnictwo UMCS Warszawa 1991, p. 171-184, idem, The Logic of Intentional Objects. A Meinongian Version of Classical Logic, Kluwer Academic Publishers, Dordrecht 1998. Contrary views have been expressed by e.g.: P. v. Inwagen, Creatures of Fiction, "American Philosophical Quarterly", vol.14, nr 4, X 1977, p. 299-308, A. Plantinga, The Nature of Necessity, Clarendon Press, Oxford 1974, p. 159-160.

${ }^{4}$ J. Paśniczek, Struktura ontologiczna przedmiotów nieistniejacych: Meinong a Ingarden [Ontological Structure of Nonexistent Objects: Meinong vs. Ingarden], ,Studia Filozoficzne”, nr 4(221), 1984, p. 29. 
understanding of a quality, we can assume that they are exemplified by any predicative expression, including existential attributes. Studies reveal characteristic traits of fictional (which differentiate them from real objects), of which the most significant are as follows:

1. Fictional objects are not ontological complete, i.e. for some qualities, neither the quality itself nor its negation can be attributed to them (e.g. Sherlock Holmes was neither an orphan or a non-orphan). It is due to the fact that the number of qualities attributed to a given object in a work of fiction is by principle finite (as in our consciousness only a finite number of representations can occur, which indicates that incompleteness is characteristic of all non-real, intentional objects).

2. Fictional objects are characterised by double structures of predication. On the one hand, we say that e.g. Pinocchio is a puppet, that his nose grows longer when he lies, that he is wooden, etc. - all of which are qualities attributed to Pinocchio in the fictional world created by C. Collodi. In doing so, we represent the qualities of Pinocchio in accordance with the way he was intentionally created by the author. On the other hand, however, a number of qualities can be attributed to Pinocchio through the treatment of the object of fiction qua an object of fiction. These include qualities such as the fact that he is a fictional character, that he is incomplete, that he is a nonexistent object, that he has been created by C. Collodi, etc. These are the object's qualities in the real world, where it constitutes a certain real entity - it is an object of consciousness. It is noteworthy at this point that if we neglect the double structure of predication, we would have to treat every fictional object as inconsistent, as it would simultaneously be fictional (in the real world) and real (in the fictional world). ${ }^{5}$

3. Fictional objects may be inconsistent, e.g. a round square, a married bachelor, a communist capitalist. It should be emphasized that inconsistent qualities are understood here as qualities excluding each other necessarily (intentionally), rather than extensionally (a golden mountain, although nonexistent, is not an inconsistent object). ${ }^{6}$ Objects such as these are rather rare, but they remain a testimony to the power of creative (intentional) acts.

The goal of research into the logic of fiction is, in the most general sense, to define the truth conditions for propositions referring to fictional objects. Given the fact that objects of this sort vary from real objects in terms of their ontological status, neither classical nor non-classical logic whose primary point of reference is the real world can aspire to the role of the logic of fiction.

It would seem that the above conclusions exclude by default the use of systems such as S. Leśniewski's ontology ( $\mathbf{L O})$, as $\mathbf{L O}$ is in essence a logic of names which assumes the precedence of primary laws and principles of the classical calculus of propositions and quantifiers. $^{8}$ The language of $\mathbf{L O}$ also includes all semantic categories which can be

\footnotetext{
${ }^{5}$ J. Paśniczek, Meinongowska wersja logiki klasycznej, p. 180-187.

${ }^{6}$ J. Paśniczek,, Struktura ontologiczna przedmiotów nieistniejacych: Meinong a Ingarden, p. 30.

${ }^{7}$ J. Paśniczek, Meinongowska wersja ..., p. 160 and cont.

${ }^{8}$ To be more precise, ontology is built on the so called prototetics - a system of propositional logic also constructed by S. Leśniewski. In many respects prototetics surpasses the classical propositional calculus - for instance, it includes functor variables which can be quantifiable similarly to propositional variables. The system also includes an extensionality principle and definitional rules. Given that identity is the only primary term used,
} 
classified under two primary categories - propositions and names. LO includes one primary constant (in many respects reminiscent of the Latin word est), whose meaning is determined by the system's sole axiom:

$$
\text { (Ax) } A \epsilon B \equiv \exists_{C} C \epsilon A \wedge \forall_{C, D}(C \epsilon D \wedge D \epsilon A \rightarrow C \epsilon D) \wedge \forall_{C}(C \epsilon A \rightarrow C \epsilon B)
$$

At the same time, however, LO allows meaningful usage of empty names and the fairly common nominalist interpretation of $\mathbf{L O}$ is not enforced by the system itself. Besides, attempts have been made (satisfactory attempts in the opinion of their authors) to employ this system in the analysis of fictional objects. The most notable of the same were those undertaken by K. Ajdukiewicz, M. Marciszewski, and J. Pelc. ${ }^{9}$ In terms of the subject matter relevant to this discussion, Pelc contents himself with reiterating Adjukiewicz's argumentation, therefore we will focus our attention on the positions presented by the other two authors.

Both Adjukiewicz and Marciszewski justify their choice by indicating two characteristic features of $\mathbf{L O}$ :

1. In the L-system, all names (general, individual, empty) belong to the same category of names. (Whether a given name is general, individual or empty does not influence the sense of an expression, only, at best, its logical value. $)^{10}$

2. Expressions of L-system reflect certain qualities of the natural language (particularly languages deprived of articles, such as Polish). "The fact is that the structures of all sentences formed by the functor "is" are the same regardless of whether during the transcription into the language of sets we choose to add "is" by using the symbol of inclusion, identity or belonging to a set. Therefore, as we move from the proposition of the type $a$ is $b$ to the type $a$ exists, we will not have to, should we use ontological formalism, decide each time which of the translations was correct in the given case." 11

Adjukiewicz and Marciszewski disagree with respect to the criterion on the basis of which a given object is recognised as intentional. For Ajdukiewicz, the basis for treating an object as intentional ("existing intentionally") is the emergence of the object's name in the considered context (work of fiction). Meanwhile, Marciszewski extends this criterion

there is no definitional connection, thus all definitions are simultaneously theses of the system. Ontology itself is also a system richer than the classical calculus of names - it includes, among other elements, the calculus of predicates, calculus of classes, theory of relations including identity (ontology is one of very few systems in logic where the functor of identity is a definable rather than primary term), and even a part of Boole's algebra. Definitions in ontology simultaneously constitute postulates of the system. For more information on Leśniewski's systems, see: E. C. Luschei, The Logical Systems of Leśniewski, North-Holland Pub. Co, Amsterdam 1962, J. Srzednicki, V. F. Rickey (eds.), Leśniewski’s Systems. Ontology and Mereology, Kluwer Academic Publishers, Dordrecht 1984 We should observe, however, that in certain respects ontology is inferior to the classical calculus of predicates - it cannot express multi-argument predication (or to be precise, it degenerates into a single-argument predication). Cf. J. Paśniczek, Ontologia Leśniewskiego a rachunek predykatów [Leśniewski's Ontology and the Calculus of Predicates], [w:] Między logikq a etyka [Betwin logic and ethics], red. Paśniczek J. et al., Wydawnictwo UMCS, Lublin 1995, p. 45-51.

${ }^{9}$ See K. Ajdukiewicz, $W$ sprawie pojęcia istnienia [In respect to the notion of existence], [w:] idem, Jezzyk $i$ poznanie, tom 2, PWN, Warszawa 1985, p. 143-154, W. Marciszewski, Problem istnienia przedmiotów intencjonalnych [The problem of existence of intentional objects], "Studia Semiotyczne", IV, 1973, p. 189-206, J. Pelc, Some Semiotic Considerations Concerning Intensional Expressions and Intentional Objects, "Logique et Analyse", 79, 1977, p. 244-267.

${ }^{10}$ It is related to the fact that unlike in the classical calculus of predicates, the expression " $x=x$ " is not a proposition of LO. The equivalent for this proposition in LO is the so called ontological law of identity: A€V $\rightarrow$ $A=A$, which means that "every object is identical to itself".

${ }^{11}$ W. Marciszewski, Problem istnienia przedmiotów intencjonalnych, p. 193. 
beyond texts currently existing to include existing texts, also potentially, in one's consciousness. In order to particularize the concept of acceptance, he introduces an axiomatic system of acceptance - $\boldsymbol{U}$. As a consequence, Maciszewski is forced to exclude inconsistent objects from the domain of intentional objects. His para-formal justification of this step is presented as follows. He begins by considering a sentence from a hypothetical text:

\section{(*) Ameteros is a son of a childless mother.}

As stipulated by the $\boldsymbol{U}$ system, he rejects this sentence and concludes that assuming that "Ameteros" does not appear in any other sentences of the language $L$, there are no grounds for acceptance Ameteros as an intentional object. (The language $L$ is, according to Marciszewski, in the case of the given text, the language of LO plus names used in the text that can be substituted by $\mathbf{L O}$ variables, or in the case of a potential text, "the part of the author's language which was used in the creation of the given potential text"). What happens, however, if "Ameteros" does appear in another sentence of the given language, for instance:

\section{(**) Ameteros proved Riemann hypothesis.}

In that case, we are obliged to accept Ameteros as an intentional object. But then, consequently, there are also no grounds for rejecting Ameteros as used in sentence (*). Furthermore, an additional complication may occur when, for instance, we discover that the statement "proved Riemann hypothesis" is just as inconsistent as "son of a childless mother". In that case all that we can do is assume that inconsistent objects are a priori excluded from the domain of intentional objects.

Probably aware of how weak the proposed evidence is, Marciszewski attempts to strengthen it by presenting the following line of reasoning: we sometimes talk of necessary propositions that they are propositions whose negation "is unthinkable", which simply means that negating them would produce an inconsistency, so "there is an intuitional awareness that inconsistent objects are inconceivable". ${ }^{12}$

Apart from the question of the actual exactness of the above description of a necessary proposition, it seems that the quoted phrase "is unthinkable" is in fact an abbreviation for "is unthinkable that the negation of the necessary proposition could be the true proposition", or "is assertively unthinkable". Moreover, should we take the meaning of the phrase "is unthinkable" literally, how would we be able to conclude that a negation of a necessary proposition leads to a inconsistency, if by principle we exclude the possibility of the inconsistency occurring within our consciousness. The discussed argumentation is then flawed by the classic fallacy of equivocation, as the expression "is unthinkable" is used in two separate meanings: literally and figuratively. Marciszewski himself admits that the exclusion of inconsistent objects from the domain of intentional objects must not necessarily be conclusive (although he fails to provide compelling arguments for even a temporary exclusion). The main reason behind rejecting these objects is most likely adoption of the $\boldsymbol{U}$ system. The second and third axiom of the $\boldsymbol{U}$ system read as follows:

\footnotetext{
${ }^{12}$ W. Marciszewski, Problem istnienia przedmiotów intencjonalnych, p. 198.
} 
$(\mathrm{Ax} 2) U x(p \rightarrow q) \rightarrow(U x p \rightarrow U x q)$

$(\mathrm{Ax} 3) p$ is a tautology in $U x p$

where $U x p$ reads - " $x$ accepts $p "$. By doing the appropriate substitution in (Ax3), we receive:

(1) $(p \wedge \sim p \rightarrow q) \rightarrow U x(p \wedge \sim p \rightarrow q)$,

where $p, q$ represent any sentences. Thus, after substitution in (Ax2), we receive:

(2) $U x(p \wedge \sim p \rightarrow q) \rightarrow(U x(p \wedge \sim p) \rightarrow U x q)$.

Therefore, recognising inconsistencies results in explosion of the system, i.e. the necessity to accept any proposition whatsoever, which naturally renders the system completely superfluous. In an attempt to maintain the $\boldsymbol{U}$ system, Marciszewski was forced to partition the homogenous depiction of intentional objects and introduce his rather unintuitive distinctions.

The proposition $\left(^{*}\right)$ can also be analysed in a way which allows the $\boldsymbol{U}$ system to be maintained, while at the same time does not force us to exclude inconsistent objects. We can assume that the inconsistency lies solely with the qualities attributed to the object $\boldsymbol{a}$ in both propositions. In this case, from the proposition $(*)$ follow the propositions:

$(* * *)$ a is Ameteros's mother, and

$(* * * *)$ a is not Ameteros's mother,

which are not logically inconsistent. Now, that propositional inconsistency has been avoided, what remains is to formulate an applicable theory of descriptions on the basis of classical two-valued logic. Such a solution to the described problem is offered for instance by J. Paśniczek. ${ }^{13}$

Examples of inconsistent objects analysed by Marciszkiewicz are so trivial (vide Ameteros) that excluding them from the domain of intentional objects would not be particularly detrimental. However, objects such as e.g. a set comprising (exclusively) all sets which are not their own elements, or the universal set (the set of all sets) ${ }^{14}$, are no longer trivial matters. A characteristic quality of these objects is the fact that their inconsistency is not evident or obvious, it can only be discovered in the course of

\footnotetext{
${ }^{13}$ J. Paśniczek, O przedmiotach sprzecznych [On inconsistent objects], „Studia Filozoficzne”, nr 7 (224), 1984, p. 52-57.

${ }^{14}$ We should observe that the notion of the universal set is not inconsistent in itself, it only proves to be so in the light of the standard set theory. As a consequence, we arrive at the obvious conclusion that such a set does not exist. However, the same does not imply that the set theory itself, by employing the notion, also becomes inconsistent. It is sufficient to consider the universal set as a so called proper class. Proper classes can be arguments of all classical functors of the set theory, e.g. the sum, inclusion, or product. They are only unable to be the left argument of the functor " $\epsilon$ " ("is an element of") When we accepts the above conditions, we evade inconsistency in considerations which employ the notion of a proper class (notably, Russell's paradox is based on this very fact). To sum up, we may employ the notion of a proper class when we discuss its elements; should we try to treat it as an element of a set, we end up with inconsistency.
} 
particular inspection. Notwithstanding the above, as inconsistency is theoretically admissible, it must be considered in the development of the theory of objects of fiction, rather than resort to an unsubstantiated division of the sphere of nonexistent objects based solely on pragmatic reasons.

Based on the earlier definition of an incomplete object, we can surmise that for a certain $B$, the following formulas will hold true for said object:

(I) $\neg A$ is $B, \neg A$ is $\sim B$

By referring to the abovementioned quality of LO, (I) can be expressed in the Lsystem with the use of one of the functors of inclusion:

(II) $\neg A \subset B \wedge \neg A \subset \sim B$

The functor " $\subset$ " can be defined as follows:

(III) $A \subset B \leftrightarrow \forall_{C}(C$ ? $A \rightarrow C$ ? $B)$

" $A \subset B$ " reads as: "any $A$ is $B$ ". It is the so called functor of weak (i.e. general) inclusion. It is evident that the above formula reflects the definition of inclusion in set theory, as far as the symbol "囵" is substituted by the linking phrase "is an element of". 15 Z. Stachniak (1981) suggested semantics for LO which implies that for certain $A, B$ the proposition (II) is true for this system. Z. Stachniak also proved the completeness of LO, which means that all true propositions in any model can be derived from LO axioms. Thus, LO allows us to nontrivially consider incomplete objects.

Let us now consider how $\mathbf{L O}$ applies to the analysis of inconsistent objects. Inconsistent objects are nonexistent, i.e.:

(IV) $A, B$ are inconsistent $\rightarrow$ non-ex $A$, non-ex $B$

In the L-system, the expression non-exA is defined as follows:

(V) non-e $x A \leftrightarrow \neg \exists \mathrm{c} C$ ? $A$

Thus, from the assumption that $\mathrm{A}$ is inconsistent, we receive:

(VI) $\forall_{C}(C$ ? $A \rightarrow C$ ? $B)$, and analogically for $B$,

(VII) $\forall_{C}(C$ ? $B \rightarrow C$ ? $A)$,

\footnotetext{
${ }^{15}$ The choice of the linking phrase is justified by the fact that its meaning remains semantically close to the meaning of the word "is" in the natural language. The original functor LO - " $\square$ " can be used nontrivially only if its arguments are individual names. Besides that, individual inclusion (" $\square$ ") implies general inclusion (" $\subset$ "): $A \square B \rightarrow A \subset B$. See J. Paśniczek, Meinong's Ontology vs. Leśniewski’s Ontology (Toward a Meinongian calculus of names), "Axiomathes", vol. 7 no. 1-2, 1996, p. 279-286.
} 
From (VI) and (VII) follows:

$$
\text { (VIII) } \forall_{C}(C \text { ? } A \leftrightarrow C \text { 回 } B) \leftrightarrow A \circ B,
$$

which corresponds to the definition of the equality functor (in other words - weak identity) in LO.

It can be easily demonstrated that the following expression is a thesis of LO:

$$
\text { (IX) } A \circ B \rightarrow(\alpha \rightarrow \alpha(A / B)) \text {, }
$$

here the expression $(A / B)$ follows from $\alpha$ through substitution of the variable $A$ with the variable $B .{ }^{16}$ I.e.:

$$
\text { (X) } A, B \text { are inconsistent } \rightarrow(\alpha \rightarrow \alpha(A / B))
$$

Therefore, all inconsistent objects have exactly the same qualities, however we choose to interpret the fact of having qualities in $\mathbf{L O}$.

As already mentioned above, the characteristic quality of inconsistent objects is that for certain qualities both the given quality and its negation belong to the object's ontological predication. Thus, in the case of a inconsistent object, for a certain $B$, the following formulas will hold true:

$$
\text { (XI) } A \text { is } B, A \text { is } \sim B
$$

It seems that the only $\mathbf{L O}$ functor allowing a nontrivial consideration of inconsistent objects is the functor of inclusion " $\subset$ " as defined above. In that case, while considering a inconsistent object in $\mathbf{L O}$, for a certain $B$, the following formulas will hold true:

$$
\text { (XII) } A \subset B \wedge A \subset \sim B
$$

Although the following expression is a thesis of LO:

$$
\text { (XIII) non-exA } \rightarrow \forall_{B} A \subset B,
$$

which means that a nonexistent object (particularly if it is inconsistent) can be assigned any quality whatsoever. To sum up the implications of (X) and (XIII): in LO, any inconsistent object possesses any quality and all inconsistent objects possess the same qualities, i.e. all nonexistent objects are identical (in the sense attributed to the functor "०"), therefore we are in fact able to only discuss a single nonexistent object. ${ }^{17}$ Whereas

\footnotetext{
${ }^{16}$ Cf. J Srzednicki, V. F. Rickey (eds.), Leśniewski’s Systems. Ontology and Mereology, p. 105.

${ }^{17}$ Given the fact that the L-system's definitions are its theses, there is the theoretical possibility to introduce an infinite number of new functors - including functors of inclusion. Qualities of the L-system and the already defined functors of inclusion allow us to conclude that the functor " $\subset$ " is and shall remain the only functor that can be employed in nontrivial consideration of nonexistent objects. The primary term of the L-system " $\square$ " is useless in the context of such deliberations. The initial element in the conjunction in sole axiom of the L-system
} 
should we accept the thesis that there are nonexistent objects, then we shall also intuitively assume certain nontrivial knowledge about them. Let us for instance consider inconsistent objects - a round square and a married bachelor. We would intuitively recognise that:

1. a round square is round

2. a round square is square

3. a married bachelor is married

4. a married bachelor is a bachelor

While less intuitive claims would include e.g.:

5. a round square is married

6. a round square is made of chocolate

7. a round square is in love with a triangle

8. a married bachelor is round

9. a married bachelor is made of chocolate

10. a married bachelor is in love with a triangle, etc.

In the L-system, all statements 5-10 are correct and true expressions. Thus, employing $\mathbf{L O}$ in an analysis of inconsistent objects is simply pointless. And since, as I tried to demonstrate above, exclusion of inconsistent objects from objects of fiction is counterintuitive and unsubstantiated, we can conclude that $\mathbf{L O}$ is not suited for an analysis of fictional objects, or nonexistent objects in general.

\section{4.}

To sum up all of the above considerations let us reiterate that any attempts to employ Leśniewski's ontology (in its original form $^{18}$ ) in the analysis of objects of fiction is doomed to failure. Contrary to our common, everyday intuition which allows us to instantly distinguish a square circle from a triangular square, LO allows us to discuss only a single inconsistent object. At the same time, the only tangible argument supporting the exclusion of inconsistent objects from the realm of fictional objects (or more broadly intentional objects) is the attachment to the two-valued classical logic, which seems to be inapplicable in the analysis of inconsistent objects. However, a closer analysis of objects of fiction reveals the duality of their predication, and consequently two ways in which they are to be treated: as objects of fiction and as objects of representation. This in turn allows us to construct systems of logic of fiction, in which we are not required (at least not

is as follows: $\exists{ }_{C} C \square A$. On the other hand, the thesis of the L-system: $\forall_{C} \sim C \square A$ is true for all impossible objects. Naturally, an expression with the functor " $\square$ " describing an impossible object could not be true.

${ }^{18}$ A significant extension of Leśniewski's ontology which actually allows for nontrivial observations on inconsistent objects has been proposed by J. Paśniczek, Meinong's Ontology vs. Leśniewski's Ontology (Toward a Meinongian calculus of names). 
completely) to give up the two-valued nature of or classical logic or get rid of the basic laws of said logic (e.g. law of excluded middle or law of non-contradiction). ${ }^{19}$ Therefore, when undertaking an analysis of objects of fiction (nonexistent, intentional, abstract) it is far more advisable to employ systems constructed with this type of analyses in mind, rather than LO which forces us to partition the uniform depiction of fictional objects. Besides, it is in fact those systems, rather than LO, that seem to aspire to constitute a comprehensive structure and not just a local ontology understood as a descriptive science portraying all possible and available disciplines.

\section{REFERENCES}

[1] Ajdukiewicz K., W sprawie pojęcia istnienia [In respect to the notion of existence], [w:] idem, Język i poznanie, tom 2, PWN, Warszawa 1985, p. 143-154.

[2] Inwagen P. van, Creatures of Fiction, “American Philosophy Quarterly", Vol. 14 no. 4, 1977, p. 299-308.

[3] Luschei E. C., The Logical Systems of Leśniewski, North-Holland Pub. Co., Amsterdam 1962.

[4] Marciszewski W., Problem istnienia przedmiotów intencjonalnych [The problem of existence of intentional objects], "Studia Semiotyczne", IV, 1973, p. 189-206.

[5] Paśniczek J., Logika fikcji [Logic of Fiction], Wydawnictwo UMCS, Lublin 1984.

[6] Paśniczek J., Struktura ontologiczna przedmiotów nieistniejacych: Meinong a Ingarden [Ontological Structure of Nonexistent Objects: Meinong vs. Ingarden], „Studia Filozoficzne", nr 4(221), 1984, p. 27-41.

[7] Paśniczek J., O przedmiotach sprzecznych [On inconsistent objects], „Studia Filozoficzne", nr 7 (224), 1984, p. 52-57.

[8] Paśniczek J., Meinongowska wersja logiki klasycznej [Meinongian Version of Calssical Logic], Wydawnictwo UMCS, Lublin 1988.

[9] Paśniczek J., Problemy logiki fikcji [Problems of the Logic of Fiction], [w:] Język, znaczenie, rozumienie, relatywizm [Language, Meaning, Comprehension, Relativism], red. Muszyński Z., Wydawnictwo UMCS, Warszawa 1991, p. 171-184.

[10] Paśniczek J., Ontologia Leśniewskiego a rachunek predykatów [Leśniewski's Ontology and the Calculus of Predicates], [w:] Między logikq a etyka [Betwin logic and ethics], red. Paśniczek J. et al., Wydawnictwo UMCS, Lublin 1995, p. 45-51.

[11] Paśniczek J., Meinong's Ontology vs. Leśniewski's Ontology (Toward a Meinongian calculus of names), “Axiomathes”, vol. 7 no. 1-2, 1996, p. 279-286.

[12] Paśniczek J., The Logic of Intentional Objects. A Meinongian Version of Classical Logic, Kluwer Academic Publishers, Dordrecht 1998.

[13] Pelc J., Some Semiotic Considerations Concerning Intensional Expressions and Intentional Objects, "Logique et Analyse", 79, 1977, p. 244-267.

[14] Plantinga A., The Nature of Necessity, Clarendon Press, Oxford 1974.

[15] Smith B., An Essay in Formal Ontology, "Grazer Philosophische Studien", 6, 1978, p. 39-62.

[16] Smith B., Ingarden vs. Meinong on the Logic of Fiction, "Philosophy and Phenomenological Research", 16, 1980, p. 93-105.

\footnotetext{
${ }^{19}$ B. Smith, Ingarden vs. Meinong on the Logic of Fiction, J. Paśniczek, Logika fikcji, idem, Meinongowska wersja logiki klasycznej.
} 
[17] Stachniak Z., Introduction to Model Theory for Leśniewski's Ontology, Wydawnictwo Uniwersytetu Wrocławskiego, Wrocław 1981.

[18] Srzednicki J., Rickey V. F. (eds.), Leśniewski's Systems. Ontology and Mereology, Kluwer Academic Publishers, Dordrecht 1984.

\section{O ZASTOSOWANIU ONTOLOGII LEŚNIEWSKIEGO DO ANALIZY PRZEDMIOTÓW FIKCYJNYCH}

Artykuł omawia zasadność stosowania Ontologii Leśniewskiego (LO) do analizy przedmiotów fikcyjnych. Próby takie podejmowane były przez K. Ajdukiewicza, W. Marciszewskiego i J. Pelca. Krótko zostają przedstawione cechy charakterystyczne przedmiotów fikcyjnych: niezupełność ontologiczna, podwójna struktura uposażenia (predykacji) oraz możliwość występowania sprzeczności. Następnie zostają omówione główne cechy LO. W dalszej kolejności analizuje się zasadność stosowania LO do analizy przedmiotów niezupełnych i sprzecznych. Okazuje się, że o ile LO sprawdza się przy analizie przedmiotów niezupełnych, to jednak zawodzi przy analizie przedmiotów sprzecznych.

Słowa kluczowe: K. Ajdukiewicz, S. Leśniewski, W. Marciszewski, J. Paśniczek, J. Pelc, logika fikcji, logika klasyczna, niezupełność, sprzeczność.

DOI:10.7862/rz.2012.einh.25 